6. Захер-Мазох Л. фон. Дванадцятий сніданок. Всесвіт. 2006. №5/6. C.202-206.

7. Захер-Мазох Л. фон. Мандрівні комедіанти. Харків, 2020. 250 с.

8. Крафт-Эбинг Р. Половая психопатия. М., 2013. 624 с.

9. Сварник Г. Джерела до біографії Леопольда фон Захер-Мазоха та його родини у Галичині. Незалежний культурологічний часопис «ЇІ». 2017. Число 87.

10. Середа О. Леопольд фон Захер-Мазох i український національний рух у Галичині у 60-х роках XIX ст. Україна: культурна спадщина, нащіональна свідомість, державність. 1998. Вип. 5.

11. Фрейд 3. О психоанализе. «Ребенка бьют»: к вопросу о происхождении сексуальных извращений. Москва, 2008. 140 с.

12. Фрейд 3. О психоанализе. Пять лекций. Методика и техника психоанализа. С.-Пбг., 1998. 224 с.

13. Фрейд 3. Экономическая проблема мазохизма. Психоаналіз. 2011. № 1 (15). С. 8-19.

DOI https://doi.org/10.30525/978-9934-26-073-5-2-2

\title{
НЕЙМОВІРНІ ДИВА РІЗДВЯНИХ ІСТОРІЙ
}

\author{
Колінько О. П. \\ доктор філологічних наук, \\ професор кафедри украӥнської та зарубіжної літератури \\ і порівняльного літературознавства \\ Бердянського державного педагогічного університету \\ м. Бердянськ, Запорізька область, Україна
}

Твори різдвяної тематики - досить вагомий жанровий пласт літератури, яким цікавляться науковці (X. Баран, I. Буркут, С. Душечкіна, О. Калениченко, М. Кучерська, І. Ліпницька, О. Приймачук, Л. Сирота, Н. Старигіна та ін.). Дослідники простежують генезу святочного оповідання, порушують питання про його жанровий канон, про схожість та відмінність різдвяного та святочного жанру, вивчають особливості хронотопу різдвяної прози, аналізують рецепцію різдвяних оповідань зарубіжних письменників у творах українських та російських митців. Однак дослідження, присвячені сучасному стану жанру та його художнім константам, серед яких найпоширеніше - диво, практично відсутні, хоча сучасні автори активно звертаються до різдвяних історій, тематика яких 
багатоманітна в своїх проявах і варіаціях та досить приваблива для сучасного читача.

Витоки жанру сягають давніх часів, календарно-святочних звичаїв i обрядів, в основі яких - карнавальна культура Європи і Київської Русі [3, с. 154]. Але тільки на початку XIX ст. почали з'являтися в періодичних виданнях твори письменників на цю тему (наприклад, у 1826 році друкуються «Святочні оповідання» Н. Полєвого у «Московскому телеграфі»; в 1835 р. в журналі «Московитянин» публікується повість «Зимовий вечір» Д. В. Григоровича та ін.). Галицькі часописи дещо пізніше, в першій третині XX ст., почали формувати святкові номери до Різдва. Журнально-газетний формат пояснюється i комерційними інтересами, і соціальними. Невеликі за обсягом оповідання, новели, нариси, есе видавці публікували з метою найбільшого залучення дописувачів і читачів - твори вважалися атрибутом «легкого чтива», інтригували цікавим змістом і очікуванням дива напередодні або під час святкування Нового року, Різдва Христового: більшість людей, дітей, втомлених бідністю і злиднями сподівалися на диво, вірили в усілякі чудеса, плекали надію, що диво змінить їх життя на краще, багаті стануть прихильнішими до бідних і всі люди будуть добрими, чуйними, благородними. Окрім того, різдвяні історії відповідали бажанню письменників не тільки прислужитися своїми творами масовому читачеві, достукатися до прихованих в його душі добрих начал, а й утверджувати християнські цінності.

«Специфічно українським сегментом «святкового» оповідання, зазначає І. Ліпницька, - був помітно наголошений соціальний елемент $\mathrm{i}$ опис злиднів українського села, який переходить у роздуми про диво народження чи воскресіння Божого Сина. Письменники використовували вігілійну форму, щоб у простій, більш дохідливій формі промовити до сердець і нагадати своїм читачам про віру в Бога, добро та любов» [4]. У творах українських письменників XIX ст., присвячених новорічно-різдвяним святам, відбуваються дива, які контрастують 3 гуманною ідеєю Різдва Христового, бо жорстока реальність, соціальна нерівність вносили свої корективи: замість християнської толерантності і любові - людська черствість, яка часто не зникає навіть під впливом різдвяної аури і яку не в змозі подолати навіть Спаситель, в честь народження якого існує це свято, зумовлює крихкість надій, нездійсненність мрій, розчарування («За що?», «Перша зірка», «Його святий вечір», «Рішився» Б. Лепкого, «Святий вечір» В. Стефаника, «Різдвяний вечір» Г. Хоткевича, «Святий Николай у гарті», «Коляда» Марка Черемшини, «Заробок на свята» О. Маковея; «Чад», «Збентежена вечеря» Олени 
Пчілки; «Морозенко» Панаса Мирного; «Відьма» С. Васильченка; «Ялинка» М. Коцюбинського, «Колядники» Степана Коваліва, «Попались!» І. Нечуя-Левицького та ін.).

Російські письменники XIX ст., зберігаючи у змістових структурах різдвяних історій нравоописовий елемент, у вічну тему добра і зла також уводили соціальний аспект, ускладнюючи сюжет оголенням неблагополучності та несправедливості в суспільному житті («Ангелочек» Л. Андрєєва, «Мальчик у Христа на ёлке» Ф. Достоєвського, «Тапер», «Чудесный доктор» О. Купріна, «Ёлка Митрича» М. Телешова, «Ванька» А. Чехова, «Под Рождество обидели» М. Лєскова, Г. Петрова «Дары Артабана», М. Познякова «Счастливая и кичливая» та ін.). У творах письменників попри інші художні складові невід'ємним атрибутом завжди є різного роду чудеса, що відбуваються у Святвечір, а соціальна дійсність майстерно синтезується 3 атмосферою дива. Як смисловий центр цих творів, Різдво 3 дивом народження і пришестя Божого Сина, молитвами, святковою вечерею, незважаючи на бідність, злидні, безвихідь символізує світло, надію, сподівання на порятунок кожної душі у світі зла та несправедливості.

Багато зарубіжних письменників не оминули у своїй творчості сакральну тему Різдва Христового («Різдвяна пісня у прозі», «Дзвони» i «Цвіркун у припічку» Ч. Діккенса, «Дівчина із сірниками», «Ялинка» Г. К. Андерсена; «Синій птах» М. Метерлінка, «Лускунчик і мишачий король» Е. Т. А. Гофмана, «Дари волхвів» О. Генрі, «Різдво в мисливській хатинці» Т. Майн Ріда, «Різдвяне диво» Г. де Мопассана, «Різдвяний гість» С. Лагерлеф та ін.). Різдвяні історії зарубіжних письменників об'єднує художня домінанта - диво, яке має духовну природу і найчастіше відбувається в душах і серцях героїв, попри соціальні негаразди і підступність суєтного світу.

Різні за сюжетом і змістом твори переконують, що визначальною рисою архетипу різдвяного оповідання $\epsilon$ його значеннєва наповненість дивом - дивом любові, радості, надії. I нехай не всі розуміють сакральність і релігійну глибину цього свята, пов'язаного 3 народженням сина Божого, але всі чекають його з нетерпінням, піднесеним настроєм та гарними думками.

Сучасні автори, звертаючись до різдвяної тематики, переслідують різну мету, використовують різні художні стратегії і прийоми, мало переймаються жанровими канонами різдвяного оповідання, а більше в залежності від змістового наповнення збагачують його новими структурними елементами, орієнтуючись переважно на сучасність, на нашу добу з її проблемами й особливостями. Новорічно-різдвяні історії, 
створені українськими письменниками останнього десятиліття, вирізняються оригінальними версіями й інтерпретаціями цієї тематики й демонструють різноманітні аспекти дивовижних подій, що відбуваються 3 героями в різному часі й просторі, але обов'язково у Святвечір чи Різдво.

У процесі аналізу збірки «19 різдвяних історій» [1] була спостережена певна закономірність: одні митці приурочують до зимових і різдвяних свят помітну, ба навіть поворотну подію у житті людини, підтверджуючи думку М. Бахтіна про найсуттєвіше значення цього часопросторового континууму - зміну, життєвий перелом: «Власне слово «поріг» уже в мовленнєвому функціонуванні (поряд із реальним значенням) набуло метафоричного трактування і збігалося з моментом життєвого перелому, кризи, рішення, що змінює життя (або нерішучості, страху перетнути поріг)» [2, с. 280-281]. Це твори Мар'яни Савки «Собачого Нового року! Котячого Різдва!»; Катерини Міхаліциної «Так буває»; Володимира Бєглова «Наступного разу, коли ти зателефонуєш»; Ілларіона Павлюка «Mаріє, Різдво!»; Доржа Бату «Різдвяна магія», Богдана Жолдака «Кучугури» (різдвяне ретро); Сергія Гридіна «Про тихоню, що мав свою зірку»; Надійки Гербіш «Жовтневе Різдво Ханни»; Христі Венгринюк «Sing Halleljah to the Lord»; Галини Вдовиченко «Лорд, вівсянка і любов»; Мирослава Лаюка «Цифра 12»).

Різдвяні історії інших письменників (збірки «19 різдвяних історій») вирізняються філософським осмисленням новорічно-різдвяних подій, що відбуваються у наш час кардинальних, загальноцивілізаційних зрушень, прискореної урбанізації тощо. Ці глобальні виклики багато чого змінили у житті й психології людини, наклали відбиток на культурні традиції та звичаї, переформатувавши їх значущість і сприйняття. Відтак у містах та й більшості сіл веселі святочні обряди і дійства не могли прижитися в своєму первісному вигляді, а от родинний характер Різдва вписався в міське життя і міську культуру. Різдво зберегло сімейні традиції, коли важливо зібратися усім разом, прислухатися до свого серця, пробачити образи, зробити подарунки, але й не забути, на честь кого це свято існує, коли «по-іншому світять зорі на небі, і так особливо мерехтить перша різдвяна зірка...» [1, с. 13].

Саме про такі цінності йдеться у творі Богдани Макіяш «Світло Різдва», де вона трепетно й тонко оповідає про Різдво, яке майже розтягується на місяць, про різдвяні ярмарки, про дух веселощів, який панує на майданах великих місті і на центральних площах містечок, i де групи колядників нарешті співають «Бог предвічний народився», «нарешті згадують Того, Чиє свято, чиє Різдво сьогодні святкується» 
[1, с. 8]. Авторка намагається усе ж таки, попри любов до різдвяних ярмарків і різдвяних фільмів, подарунків, привернути увагу сучасників до християнських цінностей, щоб «Різдво було з Христом, а не без Христа, щоб Гугл писав: «Щасливого Різдва», <...> а не означував його як «одне 3 релігійних свят», і щоб «фраза «дух Різдва» не ставала заїждженим шаблоном, маркетинговим гаслом, яке так успішно приваблює покупців» [18, с. 8].

Авторська інтерпретація як християнської, так i нерелігійної проблематики суголосна філософським міркуванням щодо категорій: добро / зло, любов / ненависть, співчуття / байдужість, толерантність / нетерпимість, сакральне / профанне тощо (наприклад, оповідання Маркіяна Прохаська «Різдво поза часом», Богдани Макіяш «Світло Різдва», Христі Венгринюк «Sing Halleljah to the Lord»; Надійки Гербіш «Жовтневе Різдво Ханни»).

Різдвяні історії сучасних українських письменників вирізняє спільна риса - наповненість дивом, яке багатоманітне в своїх проявах, пов'язане як 3 подіями реального життя, так і духовного, позаяк метаморфози, навіяні різдвяним дивом (таємниця якого не піддається одномірному визначенню і розкриттю) усе ж відбуваються не тільки в реаліях земного життя, а й в душах і серцях героїв. Вони, наші сучасники, зазвичай не відзначаються релігійністю, але усвідомлюють незвичність зустрічей, змін, подій, що з ними відбуваються саме в такий сакральний час Різдва Христового.

\section{Література:}

1. 19 різдвяних історій: коротка проза. Львів: Видавництво Старого Лева, 2019. 216 с.

2. Бахтин М. Вопросы литературы и эстетики. Москва: Худ. лит., 1975. 504 с.

3. Лихачев Д., Панченко А., Понырко Н. Смех в Древней Руси. Ленинград: Наука, 1984. 295 с.

4. Ліпницька Інна. Поетика жанру «різдвяного» оповідання Богдана Лепкого. URL: https://shron1.chtyvo.org.ua/Lipnytska_Inna/Poetyka zhanru_rizdvianoho_opovidannia_Bohdana_Lepkoho.pdf?PHPSESSID=19ej4 motlahbo9dj3ihbi56qu7. 